\title{
Interval compressed vincristine, doxorubicin, cyclophosphamide alternating with ifosfamide, etoposide in patients with advanced Ewing's and other Small Round Cell Sarcomas
}

\author{
Jeremy Whelan", Atia Khan, Anand Sharma, Christian Rothermundt, Palma Dileo, Maria Michelagnoli, \\ Beatrice Seddon and Sandra Strausss
}

\begin{abstract}
Background: To evaluate tolerability and maintenance of dose intensity of 2 weekly treatment with vincristine, doxorubicin, cyclophosphamide alternating with ifosfamide, etoposide (VDC/IE) in patients with advanced small round cell sarcomas including Ewing family tumours (EFT), desmoplastic small round cell tumours (DSRCT) and undifferentiated high grade round cell sarcomas (UHGRCS).

Methods: Retrospective review of 16 patients treated at a single centre with VDC/IE. Dose received, treatment delay, toxicity and clinical outcome were recorded for each cycle up to a maximum of 14 cycles.

Results: A total 193 cycles of VDC/IE were administered to 10 patients with EFT, 4 with DSRCT and 2 with UHGRCS. Median age was 22 years with 75\% over 18 years. Metastases were present in 14 patients. The mean duration of each cycle was 16.7 days. Febrile neutropenia occurred in $14 \%$ of cycles, and grade $3 / 4$ haematologic toxicity including anaemia and thrombocytopenia in $16 \%$ and $11 \%$ of cycles respectively. Seven patients had a dose reduction. Five patients discontinued VDC/IE early due to toxicity.
\end{abstract}

Conclusions: This schedule of VDC/IE is feasible in patients with EFT and DSRCT including adults and those with metastases. Its comparison with other standard regimens for these diseases is justified.

Keywords: Ewing's sarcoma, Desmoplastic small round cell tumour, Chemotherapy, Sarcoma

\section{Background}

The Ewing's family of tumours (EFT) are the second most common malignant bone tumour seen in children and young people [1,2]. Histologically, they are characterized by small round blue cells with immunohistochemical staining for CD99 and neural markers. A reciprocal translocation between chromosomes 11 and 22 is evident in more than $85 \%$ of these tumours [3,4]. The family of small round blue cell sarcomas also includes desmoplastic small round cell tumour (DSRCT), a rare soft tissue sarcoma characteristically presenting in young males with extensive multifocal intraabdominal disease.

\footnotetext{
*Correspondence: jeremy.whelan@uclh.nhs.uk Department of Oncology, The London Sarcoma Service, University College Hospital London NHS Foundation Trust, 1st Floor Central, 250 Euston Road, London NW1 2PG, UK
}

(c) 2012 Whelan et al.; licensee BioMed Central Ltd. This is an Open Access article distributed under the terms of the Creative Commons Attribution License (http://creativecommons.org/licenses/by/2.0), which permits unrestricted use, distribution, and reproduction in any medium, provided the original work is properly cited.
EFT are used, albeit with less satisfactory results as progression and ultimately death due to disease is almost universal [5-7].

Since the introduction of multimodality treatment in EFT, survival has improved from $10 \%$ to $75 \%$ in patients with localized disease [8-11]. Since the 1980's, chemotherapy regimens have evolved both in Europe and the United States to include anthracyclines and alkylating agents with only modest variations in dose and schedule $[9,10,12-15]$. To contend with a lack of recent survival improvement or new agents with major activity, investigators have concentrated on investigating the benefits of scheduling and dose intensity.

The current European Ewing tumour Working Initiative of National Groups 1999 (EURO-EWING 99) study 
has enrolled over 3,200 patients in a study evaluating an intensive induction regimen (VIDE, vincristine, ifosfamide, doxorubicin and etoposide) and, in selected cohorts of randomized patients, high dose chemotherapy with stem cell rescue. Toxicity associated with VIDE chemotherapy is substantial. For example, neutropenia and related fever is reported in $60.8 \%$ and $65.8 \%$ of courses respectively [16].

In North America, alternative approaches to dose optimization have been explored. The Children's Oncology Group (COG) study, INT-0154, using a regimen of vincristine, doxorubicin, cyclophosphamide alternating with ifosfamide and etoposide (VDC/IE), randomized patients to an increased treatment intensity by higher doses of cyclophosphamide and ifosfamide and a decreased length of treatment to 11 cycles over 30 weeks in the test arm compared with a standard 17 cycles over 48 weeks but with equivalent total drug doses in each arm. There was no survival improvement but more toxicity in the dose intense arm [17]. In contrast a survival advantage has been reported in the preliminary results from a further COG study of patients with localized EFT, AEWSOO31, randomizing between a standard three weekly schedule and an 'interval compressed' two weekly schedule of VDC/IE, the latter made possible by growth factor support [18]. The mean cycle durations were 18.5 and 23.3 days for the two and three weekly cycles respectively. Event free survival at 3 years was significantly extended in the two weekly arm, $76 \%$ vs. $65 \%$, $\mathrm{p}=0.028$. Toxicity was similar in the two treatment arms but with the reported frequency of febrile neutropenia and other major toxicities apparently lower than those seen with VIDE. Interval compressed VDC/IE has consequently been adopted as the standard of care for future studies of EFT by COG.

There are significant advantages to defining a standard chemotherapy regimen for EFT, not least as a platform for testing new agents in an international setting, which is essential in studying rare cancers. Additional goals for all investigators are reducing both short and late toxicity in a young population of whom approximately two thirds will achieve long term survival, and of course limiting the treatment burden in those with poor prognostic factors. Whether interval compressed VDC/IE is less toxic than VIDE is speculative in the absence of comparative data. Furthermore, the AEWS0031 study was limited to patients with localised disease and had only a small proportion of patients aged over 20 years, so it may not be appropriate to extrapolate the data to the entire EFT population.

In preparation for a planned randomized comparison in Europe of first line treatment for EFT between VIDE and $\mathrm{VDC} / \mathrm{IE}$, we retrospectively examined the feasibility of interval compressed VDC/IE in patients with metastatic EFT. In recognition that less toxic treatment would be appropriate for older patients [19] and those with a poor prognosis, we did not restrict the age of our cohort, and also included those with DSRCT. This latter group responds temporarily to chemotherapy regimens used in EFT but with a 5-year survival of only 15\% [20]. Our institutional standard for DSRCT and UHGRCS includes treatment with VIDE. Identifying a more tolerable but effective regimen is a priority.

\section{Materials and methods}

\section{Patient selection}

A consecutive series of patients were treated with interval compressed VDC/IE if either ineligible for the EURO-EWING 99 study (including those with extrapulmonary metastases), or were newly diagnosed with DSRCT or UHGRCS. A histological diagnosis was required in all patients. Staging included plain X-rays and magnetic resonance imaging (MRI) or computed tomography (CT) scan of the primary site, chest CT scan and whole body technetium $\left({ }^{99 m} \mathrm{Tc}\right)$ bone scan were performed to confirm the presence of metastases. Routine assessments of renal and cardiac function were conducted at baseline, during and after therapy. Institutional ethics guidance was followed.

\section{Chemotherapy}

The VDC/IE regimen was alternate 14 day cycles of VDC (vincristine $1.4 \mathrm{mg} / \mathrm{m}^{2}$, maximum $2 \mathrm{mg}$, doxorubicin $75 \mathrm{mg} / \mathrm{m}^{2}$ and cyclophosphamide $1200 \mathrm{mg} / \mathrm{m}^{2}$ administered over 2 days) and IE (ifosfamide $9 \mathrm{gm} / \mathrm{m}^{2}$, etoposide $500 \mathrm{mg} / \mathrm{m}^{2}$ fractionated over 5 days). Patients had a full blood count measured on the day prior to the cycle due date and treatment was given if the neutrophil count was greater than $1 \times 10^{9} / \mathrm{l}$, platelet count greater than $80 \times 10^{9} / 1$ and biochemical parameters were within normal range. Nadir blood counts were not routinely measured. All patients received growth factor support with pegylated granulocyte colony stimulating factor given within $72 \mathrm{~h}$ of last chemotherapy. Toxicity was assessed using the Common Terminology Criteria for Adverse Events (CTCAE) Version 3.0. In the event of lack of recovery from toxicity, chemotherapy was delayed or modified at the discretion of the treating physician. Radiological response assessment was carried out with restaging $\mathrm{CT}$ and MRI scans after 4 and 8 cycles of treatment. Fourteen cycles of chemotherapy were planned subject to tolerability and response, with treatment interrupted after 6 cycles or 12 weeks for surgery if applicable. When radiotherapy was the primary modality for local control, this was given concurrently with chemotherapy beginning after cycle 6 and with the omission of anthracyclines from relevant cycles. 


\section{Results}

Patient characteristics

Between September 2008 and October 2011, 16 patients received 193 cycles of interval-compressed VDC/IE (Table 1). Ten patients had EFT, two had UHGRCS, and four patients had DSRCT. Fourteen (88\%) had metastatic disease and 11 patients had more than one site of metastasis. The remaining three had metastatic disease confined to the lung. Seventy per cent of patients were older than 18 years (median 22 years).

\section{Treatment}

Eight patients completed 14 cycles of VDC/IE (Table 2). Six patients discontinued VDC/IE early, 5 due to toxicity and one because of progression. These six received a median of 11 cycles (range 4-12). Patient 3 had early

Table 1 Patient demographics

\begin{tabular}{|c|c|c|}
\hline & No. of patients $(n=16)$ & $\%$ \\
\hline \multicolumn{3}{|l|}{ Age in years } \\
\hline Median (range) & $22(14-37)$ & $100 \%$ \\
\hline $14-17$ & 4 & $25 \%$ \\
\hline $18-25$ & 7 & $44 \%$ \\
\hline $25-37$ & 5 & $31 \%$ \\
\hline \multicolumn{3}{|l|}{ Sex } \\
\hline Male: Female & $12: 4$ & \\
\hline \multicolumn{3}{|l|}{ Diagnosis } \\
\hline EFT & 10 & $62.5 \%$ \\
\hline DSRCT & 4 & $25 \%$ \\
\hline UHGRCS & 2 & $12.5 \%$ \\
\hline \multicolumn{3}{|l|}{ Primary Site } \\
\hline Ewing's Sarcoma & 10 & \\
\hline Pelvis & 5 & $50 \%$ \\
\hline Kidney & 1 & $10 \%$ \\
\hline Lower extremity & 2 & $20 \%$ \\
\hline Rib & 1 & $10 \%$ \\
\hline Unknown & 1 & $10 \%$ \\
\hline UHGRCS & 2 & \\
\hline Pelvis & 1 & $50 \%$ \\
\hline Mediastinum & 1 & $50 \%$ \\
\hline \multicolumn{3}{|l|}{ Extent of disease } \\
\hline Localised & 2 & $12 \%$ \\
\hline Metastatic & 14 & $88 \%$ \\
\hline Bone only & 5 & $36 \%$ \\
\hline Lung and bone & 3 & $21 \%$ \\
\hline Lung, bone, BM & 2 & $14 \%$ \\
\hline Bone and BM & 1 & $7 \%$ \\
\hline Lung only & 3 & $21 \%$ \\
\hline
\end{tabular}

UHGRCS,Undifferentiated high grade round cell sarcoma; DSRCT, Desmoplastic small round cell tumour; BM, bone marrow. surgery after 4 cycles having experienced severe haematological and gastrointestinal toxicity. Chemotherapy was not continued post operatively and the patient remains disease free at 2 years. Patient 11 discontinued after cycle 11 due to prolonged thrombocytopenia following pelvic irradiation. Patient 2 completed 12 cycles and then developed a deep infection around a pelvic spacer inserted for radiotherapy. Patients 14 and 15 also completed 11 and 12 cycles respectively experiencing severe cumulative fatigue and haematological toxicity. $\mathrm{Pa}-$ tient 5 had progressive disease after 11 cycles. Two patients with EFT were switched to receive VDC/IE having previously commenced alternative chemotherapy regimens and did not complete all 14 cycles. Patient 6 had 3 cycles of VIDE followed by 8 cycles of VDC/IE and patient 16 had a cycle of VAC (vincristine, actinomycin$\mathrm{D}$, cyclophosphamide), then VID (vincristine, ifosfamide, doxorubicin) followed by 12 cycles of VDC/IE.

\section{Treatment interval}

The mean treatment interval for each patient was calculated from the entire treatment duration in days divided by the number of cycles that were completed in this time. The mean interval between cycles was 16.7 days (range 14 to 57 days). All 16 patients took longer than expected to complete the treatment course. Figure 1 demonstrates the total number of days delay over the entire treatment schedule for each patient. The number of days that treatment was delayed due to chemotherapy related toxicity and other causes are demonstrated for each patient in Figure 2. The main chemotherapy related cause for delay was neutropenia, febrile neutropenia and thrombocytopenia. Of the non-chemotherapy related causes, most delays were due to surgery. Chemotherapy was continued during and after radiotherapy in all but one patient who developed prolonged thrombocytopenia following pelvic radiotherapy.

\section{Dose modifications}

Nine patients (56\%), including 5 of the 8 who completed all 14 cycles, had no dose reduction, whereas 7 patients required varying dose reductions, as follows. Patient 1 required a $50 \%$ dose reduction of vincristine alone at cycle 3 due to grade 3 neuropathy but later recovered and received full dose vincristine for all future cycles. However she required a $20 \%$ dose reduction of ifosfamide and etoposide at cycle 8 due to grade 3 thrombocytopenia, anaemia and mucositis. The dose reduction continued for cycle 10 and a further $20 \%$ reduction was made at cycle 12 for on-going grade 3 bone marrow toxicity but the patient completed 14 cycles. Patient 2 had a $20 \%$ dose reduction of doxorubicin and cyclophosphamide at cycles 7,9 and 11. At cycle 10 a $20 \%$ reduction of Ifosfamide and etoposide was added 
Table 2 Demonstrates the treatment received by each patient including the local treatment and outcome to date

\begin{tabular}{|c|c|c|c|c|c|c|c|c|c|c|c|}
\hline $\begin{array}{l}\text { Patient } \\
\text { No. }\end{array}$ & $\begin{array}{l}\text { Age at } \\
\text { diagnosis }\end{array}$ & Gender & Diagnosis & $\begin{array}{l}\text { Primary } \\
\text { site }\end{array}$ & $\begin{array}{l}\text { Site of } \\
\text { metastases }\end{array}$ & $\begin{array}{l}\text { Prior } \\
\text { chemo }\end{array}$ & $\begin{array}{l}\text { No of } \\
\text { VDC/IE } \\
\text { cycles }\end{array}$ & $\begin{array}{l}\text { Cycle } \\
\text { treatment } \\
\text { Interval } \\
\text { (days) }\end{array}$ & $\begin{array}{l}\text { Dose } \\
\text { reduction }\end{array}$ & $\begin{array}{l}\text { Local } \\
\text { treatment }\end{array}$ & Outcome \\
\hline 1 & 14 & $\mathrm{~F}$ & EFT & Kidney & $\begin{array}{l}\text { Bone, } \\
\text { peritoneum }\end{array}$ & No & 14 & 19.9 & Yes & $\begin{array}{l}\text { Surgery, R1 resection, poor response } \\
\text { to chemo on histology }\end{array}$ & $\begin{array}{l}\text { Relapsed } 3 \text { months after completing VDC/IE - } \\
\text { receiving palliative chemotherapy }\end{array}$ \\
\hline 2 & 22 & M & EFT & \|lium & $\begin{array}{l}\text { Lung, bone, } \\
\text { BM }\end{array}$ & No & 12 & 17.1 & Yes & RT - 50Gy in 30\# 2 phases & $\begin{array}{l}\text { Relapsed } 10 \text { months post treatment and died } \\
23 \text { months post treatment }\end{array}$ \\
\hline 4 & 29 & M & EFT & Femur & Bone, BM & No & 14 & 14.9 & Yes & $\begin{array}{l}\text { Surgery, R0 resection with good } \\
\text { response to chemo on histology }\end{array}$ & $\begin{array}{l}\text { Relapsed } 7 \text { months post treatment and died } \\
11 \text { months after treatment }\end{array}$ \\
\hline 5 & 15 & $\mathrm{~F}$ & EFT & Unknown & $\begin{array}{l}\text { Lung, Bone, } \\
\text { BM }\end{array}$ & No & 11 & 17.5 & Yes & None & $\begin{array}{l}\text { Progressed at cycle } 11 \text { and died } 3 \text { months } \\
\text { later }\end{array}$ \\
\hline 6 & 17 & M & EFT & \|lium & Bone & Yes & 8 & 15.4 & No & RT 55Gy in 31\# & $\begin{array}{l}\text { Relapsed } 4 \text { month post treatment. Died } 15 \\
\text { months after completing treatment. }\end{array}$ \\
\hline 7 & 29 & M & EFT & ilium & Lung, Bone & No & 14 & 16.5 & Yes & RT 45Gy in 25\# & $\begin{array}{l}\text { Progressed at the end of treatment and died } \\
3 \text { months later }\end{array}$ \\
\hline 11 & 21 & M & EFT & Sacrum & bone & No & 11 & 17.4 & No & $\begin{array}{l}\text { RT } 50.4 \mathrm{~Gy} \text { in } 28 \# \text { in } 2 \text { phases to } \\
\text { sacrum and } 55 \mathrm{~Gy} \text { in } 30 \# \text { to chest }\end{array}$ & $\begin{array}{l}\text { Relapsed } 4 \text { months post treatment and died } 6 \\
\text { months post treatment }\end{array}$ \\
\hline 12 & 19 & M & EFT & Pelvis & Bone & No & 14 & 16.5 & No & RT 55Gy in 30\# & Disease free at 4 months post treatment \\
\hline 15 & 19 & M & EFT & Metatarsal & Lung, Bone & No & 12 & 17.9 & No & $\begin{array}{l}\text { Surgery, close margins, poor } \\
\text { response to chemo on histology }\end{array}$ & $\begin{array}{l}\text { Relapsed in lung } 11 \text { months treatment and } \\
\text { then lost to follow up in } 8 \text { months after } \\
\text { relapse as living abroad. }\end{array}$ \\
\hline 16 & 17 & M & EFT & First rib & Bone & Yes & 12 & 18.5 & Yes & RT 55.8Gy in 31\# & $\begin{array}{l}\text { Died of disease } 4 \text { months after completing } \\
\text { treatment. }\end{array}$ \\
\hline 3 & 37 & $\mathrm{~F}$ & UHGRCS & \|lium & none & No & 4 & 16.2 & No & $\begin{array}{l}\text { Surgery, R0 resection. Poor } \\
\text { response to chemo on histology }\end{array}$ & Disease free 25 months post treatment \\
\hline 14 & 27 & $\mathrm{~F}$ & UHGRCS & mediastinum & None & No & 11 & 19.9 & Yes & $\begin{array}{l}\text { Surgery, R0 resection with } \\
\text { excellent response to chemo } \\
\text { on histology }\end{array}$ & Disease free 1 month post treatment \\
\hline 8 & 24 & M & DSRCT & $\mathrm{n} / \mathrm{a}$ & $\begin{array}{l}\text { Peritoneal } \\
\text { cavity, } \\
\text { lungs }\end{array}$ & No & 14 & 15.9 & No & None & $\begin{array}{l}\text { Progressed } 5 \text { months post treatment, while } \\
\text { on maintenance VAC chemotherapy and is } \\
\text { having further palliative chemo }\end{array}$ \\
\hline 9 & 31 & M & DSCRT & $\mathrm{n} / \mathrm{a}$ & $\begin{array}{l}\text { Peritoneal } \\
\text { cavity Lung, } \\
\text { bone }\end{array}$ & No & 14 & 15 & No & None & $\begin{array}{l}\text { Progressed } 4 \text { months post treatment and is } \\
\text { currently having further palliative chemo }\end{array}$ \\
\hline 10 & 19 & M & DSCRT & $\mathrm{n} / \mathrm{a}$ & $\begin{array}{l}\text { Peritoneal } \\
\text { cavity, liver }\end{array}$ & No & 14 & 14.9 & No & None & $\begin{array}{l}\text { No progression } 6 \text { months post treatment on } \\
\text { maintenance } V A C\end{array}$ \\
\hline 13 & 22 & M & DSCRT & $\mathrm{n} / \mathrm{a}$ & $\begin{array}{l}\text { Peritoneal } \\
\text { cavity }\end{array}$ & No & 14 & 14.9 & No & None & $\begin{array}{l}\text { No evidence of progression one month post } \\
\text { treatment }\end{array}$ \\
\hline
\end{tabular}

M, Male; F,Female; EFT, Ewing's family of tumors; UHGRCS,Undifferentiated high grade round cell sarcoma; DSRCT, Desmoplastic small round cell tumour; RT, radiotherapy; R1, microscopically positive margins; RO, complete excision. 


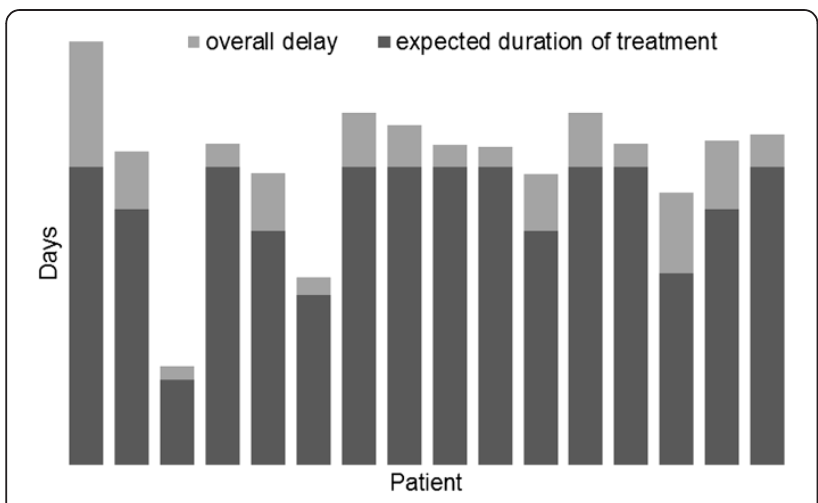

Figure 1 Duration of treatment. The expected duration of treatment for each patient in days, determined by the number of cycles received (dark grey), and the additional days required to complete treatment (light grey).

which continued for cycle 12. All reductions were due to episodes of febrile neutropenia and fatigue. Treatment was terminated at cycle 12 due to a prolonged infection surrounding his pelvic spacer. Patient 4 had a $20 \%$ dose reduction of doxorubicin alone at cycles 9 and 11 due to febrile neutropenia. Doxorubicin was omitted for cycle 13 as the patient was receiving concurrent radiotherapy. Patient 5 had the first cycle of VDC with a $20 \%$ reduction of all three drugs due to poor performance status. Subsequent cycles were given at full dose till cycle 7 when vincristine was dose reduced by $50 \%$ due to grade 3 peripheral neuropathy. This reduction continued for cycle 9 and 11 when treatment was discontinued due to progressive disease. Patient 7 had a $20 \%$ dose reduction of doxorubicin at cycle 13 alone due to a grade 3 thrombocytopenia and neutropenia. He completed 14 cycles in total. Patient 14 experienced grade 3 peripheral neuropathy at cycle 3 which led to a 50\% dose reduction of vincristine and subsequent omission from a further 4 cycles of VDC. By the end of treatment, the neuropathy

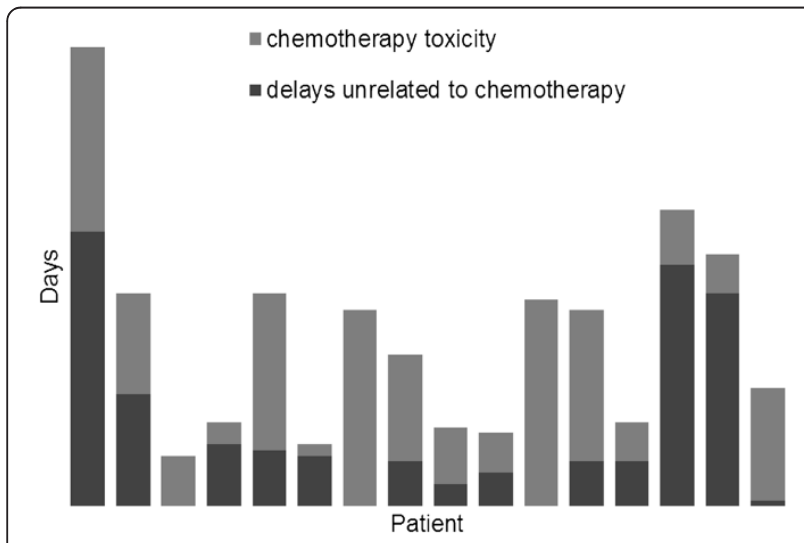

Figure 2 Reasons for Delay. Delay in days is divided between chemotherapy related toxicity (light grey) and other factors such as interruptions for surgery (dark grey). had improved to grade 2 . No other dose modifications were made and she requested discontinuation of treatment at cycle 11 due to cumulative fatigue and haematological toxicity. Finally, patient 16 had a 20\% dose reduction from cycle 5 in all drugs except vincristine because of grade 3 thrombocytopenia and mucositis.

\section{Adverse events}

There were no toxicity related deaths. The rates of grade 3 and 4 toxicities per cycle are illustrated in table 3. Grade 3 febrile neutropenia was observed in 26 cycles (13.5\%) and there were 6 episodes of non-neutropenia related infection requiring admission to hospital. Grade $3 / 4$ anaemia was recorded in 31 cycles (16\%) and thrombocytopenia in 25 cycles $(13 \%)$ on routine prechemotherapy blood counts performed on day 14. Grade 3 or 4 mucositis was observed in only 12 cycles $(6.2 \%)$. There were no grade 3 and 4 cardiac or renal toxicities and no episodes of grade 3 and 4 encephalopathy.

\section{Outcome}

All 10 patients with EFT had a radiological response to therapy (Table 2). Nine patients subsequently had local treatment to the primary site. Three patients had surgery, with a good response to chemotherapy (>90\% necrosis) evident in one. The remaining six patients had radiotherapy to the primary site. The tenth patient with EFT had widely metastatic disease with no identifiable primary tumour. Nine patients have relapsed or progressed between 1 and 11 months after completing treatment and seven have died.

The four patients with DSCRT all completed 14 cycles of treatment. All had clinical benefit from chemotherapy.

Two patients with high grade undifferentiated round cell tumours were treated. The first had stable disease

Table 3 Number of cycles complicated by grade 3 or 4 toxicity out of the total of 193 delivered cycles of VDC/IE

\begin{tabular}{lccc}
\hline $\begin{array}{l}\text { Grade } \mathbf{3} \text { \& } \mathbf{4} \text { Toxicity } \\
\text { rates/193 cycles }\end{array}$ & Grade $\mathbf{3}$ & Grade 4 & $\begin{array}{l}\text { Total } \\
\text { Grade 3 } \\
\text { and } \mathbf{4}(\%)\end{array}$ \\
\hline Febrile Neutropenia & 26 & 0 & $26(13.5)$ \\
Non-febrile neutropenia & 3 & 11 & $14(7.3)$ \\
Anaemia & 29 & 2 & $31(16.1)$ \\
Thrombocytopenia & 19 & 6 & $25(13.0)$ \\
Mucositis & 12 & 0 & $12(6.2)$ \\
Non-neutropenic infection & 6 & 0 & $6(3.1)$ \\
requiring hospital admission & 3 & 0 & $3(1.6)$ \\
Neuropathy & 3 & 0 & $3(1.6)$ \\
Fatigue & 2 & 0 & $2(1.0)$ \\
Diarrhoea & 2 & 0 & $2(1.0)$ \\
Nausea and vomiting & &
\end{tabular}


after 4 cycles of VDC/IE and underwent surgery with a poor histological response. This patient remains progression free after 25 months. The second patient underwent surgery after 8 cycles, with a complete histological response and is free from progression 3 months after completion of chemotherapy.

\section{Discussion}

In response to emerging data from the US indicating that interval compressed VDC/IE was a well-tolerated, effective regimen for EFT, we selected patients who were ineligible for randomisation in Euro EWING 99 to receive this treatment in preference to the institutional standard, VIDE [16,21]. We wished to gain preliminary experience of the feasibility of this regimen and extend its use to a population with metastatic disease and older patients, groups not represented in the randomised study from COG. The results indicate that this regimen can be safely delivered and interval compression achieved in this patient group. Although this is a small study, these data also lend support to the view that this is a tolerable regimen, even in an older patient group with considerable disease burden. Finally, we observed clinical benefit of dose compressed VDC/IE in DSRCT.

Toxicities associated with VIDE are well recorded both from the initial single institution study [21] and from a large analysis of the first 851 patients included in EURO-E.W.I.N.G. 99 [16]. A total of 4,746 courses of VIDE in 851 patients were analysed with respect to toxicity. The rate of febrile neutropenia was $60.8 \%$ with, and $65.8 \%$ without, GCSF support.

Toxicity data from the AEWSOO31 study is currently available only in abstract but reports a rate of grade $3 / 4$ febrile neutropenia of $6.9 \%$ in the two weekly arm [18]. While emphasising the very small number of patients reported here, this figure is lower than that reported here $(13.5 \%)$. However, the several differences in patient demographics may account for this. Firstly the AEWS0031 study was in a paediatric population with only 75 of the $587(12.8 \%)$ patients over the age of 18 , whereas in this study 12 patients were over the age of 18 (75\%). Secondly, the AEWS0031 study was carried out in patients who did not have metastatic disease. Again, in our cohort, the majority of patients had metastatic disease and a large overall tumour burden, 11 (69\%) patients having bone, bone marrow and lung metastases, and 7 (44\%) with primary pelvic disease.

The determinants of chemotherapy tolerance in EFT require further clarification. Comparisons of the influence of factors such as age are limited by the absence of planned prospective analyses and the reporting of cohorts containing varying proportions of children, adolescents and adults. Hence studies that report the adverse influence of younger age may contain few adults
[22]; others focus exclusively on much older adults [23]; while still others fall between these extremes [19,24]. In the largest study, from EURO-E.W.I.N.G. 99, chemotherapy toxicity was not clearly greater in older patients but dose modifications were more frequent [16]. Most clinicians will remain cautious when treating older patients or those with heavy tumour burden with the current intensive regimens discussed here.

The treatment interval for the two weekly regimen was successfully maintained in this patient cohort with a mean treatment interval of 16.7 days. This resulted in a shorter overall treatment time when compared to a 3-weekly regimen. For the 8 patients who completed all 14 cycles of treatment the average overall treatment time was 253 days, which is markedly shorter than the 294 days it takes to complete standard treatment with VIDE/VAI. In the EURO-E.W.I.N.G 99 clinical trial, dose modifications were recorded in 1020 of the 4746 courses (21\%) of all cycles. In this study, only 26 cycles were given at a reduced dose (14\%), therefore we can postulate that dose intensity was not compromised in order to maintain a shorter dose interval. Three patients terminated treatment early due to chemotherapy-related toxicity; two at cycle 11 and one at cycle 12 .

The main limitation of this study is that it is a small non-randomised cohort of patients with heterogeneity of presenting clinical features. The poor prognostic factors present in several patients and the need to gain familiarity with the regimen will have had an effect on the application of clinical thresholds for decisions on dose reductions and cessation of treatment. The information on clinical outcome is provoking but should be considered only with caution. Despite this, the data do have value in supporting the premise that this may be a less toxic regimen than VIDE, which is deliverable in patients outside of the limited eligibility criteria for AEWS0031.

In conclusion, this study demonstrates that interval compression of chemotherapy is feasible in an older and higher risk cohort of patients with EFT and other small round cell sarcomas. This schedule appears well tolerated compared with the standard European treatment of VIDE followed by VAC or VAI. We also included patients who would traditionally have a poor long term survival even with intensive chemotherapy. A shorter, less toxic regimen is an attractive option for these patients in whom life expectancy is likely to be limited by their disease. Further data regarding efficacy and long term toxicity will be available in the future as this regimen will now be compared with the VIDE/VAI schedule in a multi-centre randomised controlled trial.

Competing interest

The authors declare that they have no competing interest. 


\section{Authors' contributions}

JW conceived the study; analysed and interpreted data; drafted the manuscript. AK, AS and CR collected, analysed and interpreted the data and contributed to drafting the manuscript. BS, MM, SS contributed to the study design, collection and interpretation of data and contributed to the manuscript. All authors read and approved the final manuscript.

\section{Acknowledgements}

This work was undertaken in part at UCLH/UCL who received a proportion of funding from the Department of Health's NIHR Biomedical Research Centres funding scheme.

Received: 8 May 2012 Accepted: 6 September 2012

Published: 21 September 2012

\section{References}

1. Seddon BM, Whelan JS: Emerging chemotherapeutic strategies and the role of treatment stratification in Ewing sarcoma. Paediatr Drugs 2008 10:93-105.

2. Whelan J, McTiernan A, Cooper N, Wong YK, Francis M, Vernon S, Strauss SJ: Incidence and survival of malignant bone sarcomas in England 1979_ 2007. Int J Cancer 2011, 131:E508-517.

3. Delattre O, Zucman J, Melot T, Garau XS, Zucker JM, Lenoir GM, Ambros PF, Sheer D, Turc-Carel C, Triche TJ, et al: The Ewing family of tumors-a subgroup of small-round-cell tumors defined by specific chimeric transcripts. N Engl J Med 1994, 331:294-299.

4. Turc-Carel C, Aurias A, Mugneret F, Lizard S, Sidaner I, Volk C, Thiery JP, Olschwang S, Philip I, Berger MP, et al: Chromosomes in Ewing's sarcoma. I. An evaluation of 85 cases of remarkable consistency of $t(11 ; 22)(q 24$; q12). Cancer Genet Cytogenet 1988, 32:229-238.

5. Kushner BH, LaQuaglia MP, Wollner N, Meyers PA, Lindsley KL, Ghavimi F, Merchant TE, Boulad F, Cheung NK, Bonilla MA, et al: Desmoplastic small round-cell tumor: prolonged progression-free survival with aggressive multimodality therapy. J Clin Oncol 1996, 14:1526-1531.

6. Talarico F, lusco D, Negri L, Belinelli D: Combined resection and multiagent adjuvant chemotherapy for intra-abdominal desmoplastic small round cell tumour: case report and review of the literature. // Giornale di chirurgia 2007, 28:367-370.

7. Hayes-Jordan A, Anderson PM: The diagnosis and management of desmoplastic small round cell tumor: a review. Curr Opin Oncol 2011, 23:385-389.

8. Ferrari S, Sundby Hall K, Luksch R, Tienghi A, Wiebe T, Fagioli F, Alvegard TA, Brach Del Prever A, Tamburini A, Alberghini M, et al: Nonmetastatic Ewing family tumors: high-dose chemotherapy with stem cell rescue in poor responder patients. Results of the Italian Sarcoma Group/Scandinavian Sarcoma Group III protocol. Ann Oncol 2011, 22:1221-1227.

9. Grier HE, Krailo MD, Tarbell NJ, Link MP, Fryer CJ, Pritchard DJ, Gebhardt MC, Dickman PS, Perlman EJ, Meyers PA, et al: Addition of ifosfamide and etoposide to standard chemotherapy for Ewing's sarcoma and primitive neuroectodermal tumor of bone. N Engl J Med 2003, 348:694-701.

10. Paulussen M, Craft AW, Lewis I, Hackshaw A, Douglas C, Dunst J, Schuck A, Winkelmann W, Kohler G, Poremba C, et al: Results of the EICESS-92 Study: two randomized trials of Ewing's sarcoma treatment-cyclophosphamide compared with ifosfamide in standard-risk patients and assessment of benefit of etoposide added to standard treatment in high-risk patients. J Clin Oncol 2008, 26:4385-4393.

11. Ladenstein R, Potschger U, Le Deley MC, Whelan J, Paulussen M, Oberlin O, van den Berg H, Dirksen U, Hjorth L, Michon J, et al: Primary disseminated multifocal Ewing sarcoma: results of the Euro-EWING 99 trial. J Clin Oncol 2010, 28:3284-3291.

12. Burgert EJ, Nesbit ME, Garnsey LA, Gehan EA, Herrmann J, Vietti TJ, Cangir A, Tefft M, Evans R, Thomas $P$, et al: Multimodal therapy for the management of nonpelvic, localized Ewing's sarcoma of bone: intergroup study IESS-II. J Clin Oncol 1990, 8:1514-1524.

13. Craft AW, Cotterill SJ, Bullimore JA, Pearson D: Long-term results from the first UKCCSG Ewing's Tumour Study (ET-1). United Kingdom Children's Cancer Study Group (UKCCSG) and the Medical Research Council Bone Sarcoma Working Party. Eur J Cancer 1997, 33:1061-1069.

14. Jurgens H, Exner U, Gadner H, Harms D, Michaelis J, Sauer R, Treuner J, Voute T, Winkelmann W, Winkler K, et al: Multidisciplinary treatment of primary Ewing's sarcoma of bone. A 6-year experience of a European Cooperative Trial. Cancer 1988, 61:23-32.

15. Nesbit MJ, Gehan EA, Burgert EJ, Vietti TJ, Cangir A, Tefft M, Evans R, Thomas P, Askin FB, Kissane JM, et al: Multimodal therapy for the management of primary, nonmetastatic Ewing's sarcoma of bone: a long-term follow-up of the First Intergroup study. J Clin Oncol 1990, 8:1664-1674.

16. Juergens C, Weston C, Lewis I, Whelan J, Paulussen M, Oberlin O, Michon J, Zoubek A, Juergens $H$, Craft A: Safety assessment of intensive induction with vincristine, ifosfamide, doxorubicin, and etoposide (VIDE) in the treatment of Ewing tumors in the EURO-E.W.I.N.G. 99 clinical trial. Pediatr Blood Cancer 2006, 47:22-29.

17. Granowetter L, Womer R, Devidas M, Krailo M, Wang C, Bernstein M, Marina N, Leavey P, Gebhardt M, Healey J, et al: Dose-intensified compared with standard chemotherapy for nonmetastatic Ewing sarcoma family of tumors: a Children's Oncology Group Study. J Clin Oncol 2009, 27:2536-2541.

18. Womer R, West D, Krailo M, Dickman P, Pawel B: Chemotherapy intensification by interval compression in localised Ewing sarcoma family tumours (EFT). J Clin Oncol 2008, 26:a10504.

19. Verrill MW, Judson IR, Wiltshaw E, Thomas JM, Harmer CL, Fisher C: The use of paediatric chemotherapy protocols at full dose is both a rational and feasible treatment strategy in adults with Ewing's family tumours. Ann Oncol 1997, 8:1099-1105.

20. Stuart-Buttle CE, Smart CJ, Pritchard S, Martin D, Welch IM: Desmoplastic small round cell tumour: a review of literature and treatment options. Surg Oncol 2008, 17:107-112.

21. Strauss SJ, McTiernan A, Driver D, Hall-Craggs M, Sandison A, Cassoni AM, Kilby A, Michelagnoli M, Pringle J, Cobb J, et al: Single center experience of a new intensive induction therapy for ewing's family of tumors: feasibility, toxicity, and stem cell mobilization properties. J Clin Oncol 2003, 21:2974-2981.

22. Sharib JM, Cyrus J, Horvai A, Gray Hazard FK, Neuhaus J, Matthay KK, Goldsby R, Marina N, Dubois SG: Predictors of acute chemotherapyassociated toxicity in patients with Ewing sarcoma. Pediatr Blood Cancer 2011, doi:10.1002/pbc.

23. Pieper $\mathrm{S}$, Ranft A, Braun-Munzinger $G$, Jurgens $H$, Paulussen M, Dirksen U: Ewing's tumors over the age of 40: a retrospective analysis of 47 patients treated according to the International Clinical Trials EICESS 92 and EURO-E.W.I.N.G. 99. Onkologie 2008, 31:657-663.

24. Fizazi K, Dohollou N, Blay JY, Guerin S, Le Cesne A, Andre F, Pouillart P, Tursz T, Nguyen BB: Ewing's family of tumors in adults: multivariate analysis of survival and long-term results of multimodality therapy in 182 patients. J Clin Oncol 1998, 16:3736-3743.

doi:10.1186/2045-3329-2-12

Cite this article as: Whelan et al: Interval compressed vincristine, doxorubicin, cyclophosphamide alternating with ifosfamide, etoposide in patients with advanced Ewing's and other Small Round Cell Sarcomas. Clinical Sarcoma Research 2012 2:12.

\section{Submit your next manuscript to BioMed Central and take full advantage of:}

- Convenient online submission

- Thorough peer review

- No space constraints or color figure charges

- Immediate publication on acceptance

- Inclusion in PubMed, CAS, Scopus and Google Scholar

- Research which is freely available for redistribution 